\title{
PENGEMBANGAN MODEL PEMBELAJARAN ADAPTIF, KOOPERARTIF, AKTIF DAN REFLEKTIF (PAKAR)
}

\author{
Bambang S. Sulasmono \\ Program Studi S1 PPKn - FKIP Universitas Kristen Satya Wacana \\ Yari Dwikurnaningsih \\ Program Studi S1 Bimbingan \& Konseling - FKIP Universitas Kristen Satya Wacana
}

\begin{abstract}
ABSTRAK
Pengembangan model pembelajaran ini dimaksudkan untuk memenuhi kebutuhan akan model pembelajaran yang cocok untuk pembelajaran Pendidikan Kewarganegaraan. Hasil yang diharapkan adalah model yang memenuhi persyaratan model pembelajaran yang baik, yaitu: a) kokoh bangunan teoritisnya, b) valid topangan hasil penelitian tentang efektifitas modelnya, dan c) teruji prosedur pelaksanaan bakunya. Pengembangan model pembelajaran PAKAR ini menggunakan model umum pemecahan masalah kependidikan dari Plomp (1982) yang mencakup a) tahap penyelidikan/investigasi awal (preliminary investigation), b) tahap perancangan (design), c) tahap pengembangan (realization/ construction), d) tahap tes, evaluasi dan revisi (test, evaluation, and revision), dan e) tahap implementasi (implementation). Dalam penelitian ini, perolehan pengembangan yang dicapai baru sampai pada tahap konstruksi yaitu dengan hasil akhir prototipe model pembelajaran PAKAR. Prototipe ini sudah diuji validitas isinya melalui uji ahli atau pakar kependidikan. Pada tahun berikutnya akan dilanjutkan ke tahap tes, evaluasi dan revisi serta tahap implementasi model.
\end{abstract}

Kata kunci: pembelajaran adaptif, aktif, kooperatif, reflektif.

\section{PENDAHULUAN}

Pendidikan kewarganegaraan memiliki peran strategis dalam sebuah negara demokrasi sebab melalui pendidikan tersebut, para warga negara dipersiapkan untuk mampu menjalankan sistem demokrasi itu sendiri. International Commission of Jurist (Budiardjo, 1980) bahkan menjadikan pendidikan kewarganegaraan sebagai salah satu dari enam ciri pokok negara demokrasi. Oleh karena itu pendidikan kewarganegaraan merupakan program yang lazim dilakukan oleh semua bangsa/negara di dunia ini. Program semacam itu tidak saja dijalankan melalui jalur pendidikan formal, melainkan juga melalui berbagai sarana sosialisasi politik di masyarakat. Warganegara yang baik (good citizens) menjadi kebutuhan setiap negara/ bangsa di dunia ini.

Pendidikan kewarganegaraan dapat dipahami sebagai usaha sadar untuk mengembangkan pengetahuan, sikap dan ketrampilan peserta didik agar dapat menjadi warganegara yang baik, yaitu warga negara yang memahami, menyadari dan mampu menggunakan hak serta menjalankan kewajiban kenegaraannya secara bertanggung-jawab. Untuk maksud tersebut pendidikan kewarganegaraan minimal harus mencakup (a) penanaman ide-ide dan prinsip-prinsip etik dan moral, yang memberi arah, makna dan tujuan bagi seluruh bangsa, (b) penanaman dan pengembangan pengetahuan yang diperlukan untuk berpikir dan bertindak cerdas dalam menghadapi isu-isu kenegaraan mutakhir, serta (c) pengembangan ketrampilan, dan teknik-teknik yang diperlukan warganegara dalam menunaikan tanggungjawab kenegaraannya.

Dalam negara demokrasi pendidikan kewarganegaraan dimaksudkan untuk mengarahkan pertumbuhan dan perkembangan anak-anak dan generasi muda agar mereka mampu dan bersemangat untuk menjalankan, meningkatkan, dan memperluas kehidupan demokratis. Mereka harus mempunyai 
pengetahuan dan pemahaman tentang demokrasi, keyakinan-keyakinan, dan kesetiaan pada nilai-nilai dan prinsip-prinsip demokrasi, ketrampilan berpikir kritis dan ketrampilan memecahkan masalah, serta kemampuan untuk menerapkan teknik-teknik partisipasi kenegaraan secara cerdas dan efektif.

Pendidikan kewarganegaraan atau civic education adalah program yang dimaksudkan untuk mendidik warga negara agar menjadi pelaku aktif dalam memecahkan persoalan yang berkembang di masyarakat dan memajukan keadilan sosial. Dengan perkataan lain pendidikan kewarganegaraan berupaya menjadikan setiap warga negara menjadi warga negara yang baik, yaitu warga negara yang memahami dan menggunakan haknya secara bertanggungjawab, serta memahami dan menjalankan kewajiban-kewajiban kenegaraan dan/atau kemasyarakatannya secara tulus.

Oleh karena itu muatan pendidikan kewarganegaraan menurut Branson (1998) mencakup "civic knowledge, civic skills and civic dispositions". Sedang John J Patrick menyebut adanya "four basic component: (1) knowledge of citizenship and government in democracy, (2) cognitive skills of democratic citizenship, (3) participatory skills of democratic citizenship, and (4) virtues of dispositions of democratic citizenship" yang harus digumuli dalam pendidikan kewarganegaraan.

Pengetahuan kewarganegaraan mencakup gagasan-gagasan dan informasi-informasi dasar yang harus diketahui dan digunakan siswa agar menjadi warga negara negara demokrasi yang efektif dan bertanggungjawab. Gagasan-gagasan dasar atau konsep-konsep pokok mencakup antara lain kedaulatan rakyat, hak-hak perorangan, kebaikan bersama, otoritas, keadilan, kebebasan, konstitusionalisme dan rule of law, dan demokrasi perwakilan.

Ketrampilan-ketrampilan kewarganegaraan (civic skills) mencakup ketrampilan-ketrampilan intelektual yang diperlukan untuk memahami, menjelaskan, membandingkan dan menilai prinsip-prinsip dan praktik-praktik pemerintahan dan kewarganegaraan demokratis. Termasuk juga ketrampilanketrampilan untuk berpartisipasi yang memungkinkan warganegara memonitor dan mempengaruhi kebijakan publik.

Sedang nilai-nilai keutamaan/kebajikan kewarganegaraan (civic virtues) mencakup watak, karakter, disposisi dan komitmen yang diperlukan untuk mempertahankan dan meningkatkan pemerintahan dan kewarganegaraan demokratis. Contoh dari kebajikan kewarganegaraan adalah penghormatan pada nilai dan martabat setiap orang, keberadaban, integritas, disiplin diri, toleransi, kasih sayang, dan patriotisme. Komitmen komitmen mencakup antara lain dedikasi kepada hak-hak asasi manusia, kebaikan bersama, kesamaan derajat dan rule of law.

Komponen-komponen itulah tampaknya yang mengilhami para pengembang kurikulum mata pelajaran Kewarganegaraan di Indonesia tahun 2004. Sebab di dalam Pedoman Khusus Pengembangan Silabus dan Penilaian Mata Pelajaran Kewarganegaraan untuk SMA (Depdiknas; 2003:10) antara lain disebutkan bahwa secara garis besar mata pelajaran Kewarganegaraan terdiri dari:

a. dimensi pengetahuan kewarganegaraan (civics knowledge) yang mencakup bidang politik, hukum dan moral;

b. dimensi ketrampilan kewarganegaraan (civics skills) yang meliputi ketrampilan partisipasi dalam kehidupan berbangsa dan bernegara, dan

c. dimensi nilai-nilai kewarganegaraan (civics values) yang mencakup antara lain percaya diri, komitmen, penguasaan atas nilai religius, norma dan moral luhur, nilai keadilan, demokratis, toleransi, kebebasan individual, kebebasan berbicara, kebebasan pers, kebebasan berserikat dan berkumpul dan perlindungan terhadap minoritas. 
Menurut Kurikulum Pendidikan Dasar dan Menengah tahun 2006, mata pelajaran Pendidikan Kewarganegaraan antara lain harus mewujudkan tujuan agar peserta didik memiliki kompetensi 'berpikir secara kritis, rasional, dan kreatif dalam menanggapi isu kewarganegaraan’'(Depdiknas, 2006).

Di lain pihak Ace Suryadi, staf Litbang Depdiknas, menilai bahwa matapelajaran Pendidikan Moral Pancasila (PMP) yang kemudian berubah menjadi Pendidikan Pancasila dan Kewarganegaraan (PPKn) selama ini justru hanya menjadi alat indoktrinasi politik penguasa, yang diarahkan pada pembentukkan kesetiaan/ loyalitas pada penguasa dan menjadi pelajaran hafalan belaka (Kompas; 16-12-2000). Sementara itu stafDirjend Pendidikan Dasar dan Menengah, Anhar Gonggong, juga menyatakan bahwa 'Pemerintah sudah terlambat 25 tahun dalam memberikan pendidikan kewarganegaraan yang bertema multi kultural' (Kompas; 14-2-2001).

Dalam kaitannya dengan implemetasi kurikulum Pendidikan Kewarganegaraan tahun 2006, tampak bahwa misi yang dibebankan pada mata pelajaran PKn di atas ternyata sulit dilaksanakan oleh para Guru PKn di sekolah. Focuss Group Discussion dengan Guru-guru SMP dan SMA/K se Salatiga menegaskan adanya sejumlah problematika dalam pelaksanaan pembelajaran PKn. Problematika tersebut antara lain meliputi:

a. Muatan materi PKn begitu padat, terutama sesudah materi Tatanegara dipadukan ke dalam PKn. Oleh sebab itu maka para Guru mengalami kesulitan dalam membagi waktu yaitu antara waktu untuk mengajar konsep-konsep politik kenegaraan dan waktu untuk menanamkan nilai-nilai Pancasila.

b. Walaupun beberapa Guru sudah menerapkan pembelajaran inovatif, namun masih banyak Guru yang tetap menggunakan strategi pembelajaran yang berpusat pada Guru. Kendala yang dirasakan oleh para Guru yang inovatif adalah: (1) Sangat terbatasnya waktu yang tersedia untuk melaksanakan pembelajaran inovatif; (2) Tumpang tindihnya materi Pendidikan Kewarganegaraan antar jenjang pendidikan; (3) Rendahnya kreativitas Guru dalam mengembangkan pembelajaran inovatif; (4) Kurang memadainya sarana dan prasarana sekolah yang diperlukan untuk mengembangkan dan menerapkan pembelajaran inovatif; (5) Kurangnya dukungan dari pihak sekolah yang sebenarnya amat diperlukan Guru dalam mengembangkan pembelajaran PKn yang inovatif; (6) Motivasi siswa untuk belajar PKN rendah. Salah satu penyebab yang diduga oleh para Guru adalah karena PKn bukan mata pelajaran yang diuji-nasionalkan.

Walaupun demikian kebanyakan Guru juga menyadari adanya peluang yang tersedia bagi dilakukannya pembelajaran inovatif dalam PKn, yaitu: (1) Dewasa ini tersedia banyak model/strategi pembelajaran mutakhir bagi pembelajaran PKn; (2) Ada kebijakan kurikuler yang menekankan pentingnya pembelajaran non konvensional; (3) Status matapelajaran PKn yang tidak diuji-nasionalkan memungkinkan para Guru PKn untuk lebih leluasa melakukan pembelajaran non konvensional.

Idealisme yang dibebankan kepada mata pelajaran PKn dan temuan lapang tentang kendala dan peluang dalam pelaksanaan pembelajaran PKn di atas memumpun pikiran kita pada satu kesimpulan bahwa memang diperlukan model pembelajaran yang mampu menjembatani kesenjangan antara tujuan ideal matapelajaran PKn dengan kondisi lapang di mana mata pelajaran itu harus diajarkan. Kesenjangan di atas menunjukkan adanya kebutuhan akan model pembelajaran yang tepat untuk pencapaian tujuan pembelajaran PKn.

Masalah dalam pengembangan ini dirumuskan "model pembelajaran seperti apakah yang dapat menggairahkan belajar siswa dan sekaligus meningkatkan pencapaian belajar siswa dalam mata pelajaran Pendidikan Kewarganegaraan".

Pengembangan model pembelajaran ini dimaksudkan untuk memenuhi kebutuhan akan model pembelajaran yang cocok untuk pembelajaran Pendidikan Kewarganegaraan. Hasil yang diharapkan 
adalah model yang memenuhi persyaratan model pembelajaran yang baik, yaitu: a) kokoh bangunan teoritisnya, b) valid topangan hasil penelitian tentang efektifitas modelnya, dan c) teruji prosedur pelaksanaan bakunya.

Lebih dari itu, model pembelajaran Pendidikan Kewarganegaraan yang hendak dikembangkan ini diharapkan dapat memperkaya bahan kajian dalam studi pengembangan model pembelajaran non konvensional, memecahkan persoalan pembelajaran dalam PKn, dan sekaligus memenuhi kebutuhan akan model pembelajaran inovatif yang dapat menggairahkan belajar siswa dan meningkatkan pencapaian belajar siswa dalam mata pelajaran PKn.

Adapun manfaat yang diharapkan melalui penembangan model pembelajaran ini adalah:

a. Manfaat teoretis:

Pengembangan model PAKAR ini diharapkan dapat memperkaya bahan kajian dalam studi pengembangan model pembelajaran inovatif.

b. Manfaat praktis:

Model PAKAR yang dikembangkan diharapkan dapat memenuhi kebutuhan model pembelajaran inovatif yang dapat diaplikasikan dalam pembelajaran khususnya mata pelajaran PKn agar dapat meningkatkan motivasi dan prestasi belajar siswa dalam mata pelajaran PKn.

\section{TINJAUAN PUSTAKA}

Sesuai dengan pokok masalah dalam pengembangan ini, maka kajian pustaka di bawah ini akan mencakup a) model dan model pembelajaran dan b) langkah-langkah pengembangan model pembelajaran.

\section{Model dan Model dalam Pembelajaran}

Model menurut Silverman (2000:77) adalah keseluruhan kerangka kerja untuk melihat kenyataan. Model memberitahu kepada kita bagaimana realitas itu dan apa saja komponen dasar yang tercakup di dalamnya. Definisi lain dari model adalah abstraksi dari sistem sebenarnya, dalam gambaran yang lebih sederhana serta mempunyai tingkat persentase yang bersifat menyeluruh. Dengan perkataan lain model adalah abstraksi dari realitas dengan hanya memusatkan perhatian pada beberapa sifat dari kehidupan sebenarnya.

Dalam konteks desain instruksional, Richey (1986) membedakan antara model dan teori. Model dapat mempunyai peranan yang berbeda-beda dalam pembangunan teori. Selanjutnya Richey menyatakan bahwa model itu merupakan representasi dari realitas yang dipresentasikan dengan struktur dan susunan (order) dalam derajat/tingkat tertentu. Harre (1960, dalam Richey, 1986) memperkenalkan dua macam model, yaitu: micromorphs dan paramorphs. Model micromorphs adalah replika visual secara fisik atau replika visual dari realitas, misalnya planetarium. Sedangkan paramorphs adalah model simbolik, yang secara khusus menggunakan deskripsi-deskripsi verbal, seperti analogi verbal.

Model paramorphs secara umum dapat dikategorikan menjadi: (1) model konseptual, (2) model prosedural, dan (3) model matematik.

1) Model konseptual adalah deskripsi verbal dan umum tentang gambaran realitas. Dalam model konseptual, komponen-komponen yang berkaitan dipresentasikan dan didefinisikan secara penuh. Model konseptual mungkin didukung oleh pengalaman dan data yang terbatas. Tidak ada pernyataan-pernyataan yang jelas tentang dalil atau proposisi-proposisi yang didukung oleh data yang banyak yang dikumpulkan secara sistematis.

2) Model prosedural adalah model yang menjelaskan bagaimana langkah-langkah melakukan sebuah tugas. Dalam desain instruksional, langkah-langkah dalam sebuah model biasanya didasarkan pada 
teori dan pengalaman tentang bagaimana mencapai tujuan pembelajaran secara efektif. Dengan perkataan lain, model ini didasarkan pada pengalaman atau diturunkan dari teori atau model lain yang berkaitan.

3) Model matematik adalah persamaan-persamaan yang menjelaskan hubungan-hubungan antara berbagai macam komponen dari sebuah situasi. Dengan menerapkan data dari situasi yang baru pada model matematik, seseorang dapat menghasilkan representasi hasil-hasilnya. Untuk menemukan formula yang tepat, seseorang harus mempunyai data yang banyak dari pengalaman-pengalaman yang sama, sehingga hubungan-hubungan yang tepat dapat ditetapkan.

Richey (1986) secara khusus merangkum beragam model prosedural yang membatasi proses desain pembelajaran ke dalam tiga orientasi dasar. Pertama, model-model yang memandang desain sebagai proyek menyeluruh. Model model itu dapat diterapkan pada desain program program pelajaran, bahan ajar atau pengajaran individual. Ada 6 unsur pokok dari beragam model jenis ini, yaitu: 1) tentukan kebutuhan-kebutuhan siswa, 2) tentukan tujuan dan sasaran, 3) kembangkan prosedur penilaian, 4) rancang/ atau pilih pendekatan penyampaian, 5) ujicobakan sistem pembelajaran itu dan 6) bakukan dan pelihara sistem. Model ini berakar pada teori sistem umum, dan telah diterapkan ke dalam beragam situasi pelatihan dan pendidikan.

Kedua, adalah model model yang terkait dengan desain untuk pengajaran tertentu, yang menekankan penataan penyajian informasi. Model ini berbasis pada teori belajar dan teori pembelajaran. Model model ini dapat dikelompokkan menjadi dua yaitu (a) model model presentasi umum yang dapat diterapkan dalam sembarang jenis pembelajaran, dan (b) model untuk tugas-tugas khusus, yang memberikan tataurutan/sikuen pembelajaran untuk tugas belajar tertentu. Ketiga, model-model yang terkait dengan metode pengorganisasian bahan ajar. Model model ini berasal dari teori komunikasi dan memberikan landasan bagi pengorganisasian dan penayangan pesan-pesan. Model-model ini terutama cocok diterapkan dalam perancangan pembelajaran terperantarai (mediated instruction).

Dalam pengembangan teori desain pembelajaran, model model prosedural berfungsi sebagai sumber pengetahuan praktis berbasis pengalaman, karena model ini lahir dari refleksi dan penerapan logis jaringan teori-teori yang melandasi desain pembelajaran. Di samping itu model-model prosedural juga merupakan bagian dari penerjemahan teori dalam arti mentransformasikan proposisi-proposisi teoritis ke dalam rekomendasi-rekomendasi kerja para praktisi dalam berbagai seting. Model-model prosedural dapat menjadi pedoman pemecahan masalah berbasiskan teori.

\section{Langkah langkah Pengembangan Model Pembelajaran}

Pengembangan model pembelajaran pada dasarnya termasuk dalam bidang perancangan atau desain pembelajaran. Dalam pengembangan disain pembelajaran terdapat beberapa model pengembangan, seperti Four D Model, dari Thiagarajan Semmel and Semmel (1974), model umum pemecahan masalah kependidikan dari Plomp (1992), dan Model Pengembangan Sistem Pembelajaran dari Dick, Dick \& Carey (1990). Dari ketiga model pengembangan pembelajaran di atas, model $4 \mathrm{D}$ dari Thiagarajan dkk, dan model pengembangan sistematis pembelajaran dari Dick, dkk lebih cocok untuk merancang pembelajaran pada aras mikro. Sedang model umum pemecahan masalah pendidikan dari Plomp, lebih tepat digunakan untuk mengembangkan model pembelajaran. Oleh karena itu model yang digunakan dalam mengembangkan model pembelajaran ini adalah model umum pemecahan masalah pendidikan dari Plomp.

Model pengembangan pembelajaran dari Thiagarajan, Semmel and Semmel yang dikenal dengan "Four D-Model", terdiri dari empat tahapan pengembangan: tahap define (tahap pendefinisian), tahap design (tahap perancangan), tahap develop (tahap pengembangan), dan tahap disseminate (tahap diseminasi/penyebarluasan). 
Tahap Pendefinisian. Dalam tahap ini pengembang memunculkan dan merumuskan kebutuhankebutuhan pembelajaran. Melalui analisa pengembang menentukan tujuan-tujuan dan hambatan-hambatan bagi bahan-bahan pembelajaran. Ada lima langkah dalam tahapan ini yaitu a) front-end analisys, b) analisis siswa, c) analisis tugas, d) analisis konsep dan e) merumuskan tujuan pembelajaran. Tahap Perancangan. Tujuan tahap ini adalah merancang prototipe bahan pembelajaran. Tahap ini dapat dimulai sesudah tujuan-tujuan pembelajaran disusun. Tahap ini mencakup langkah-langkah a) penyusunan tes beracuan kriteria, b) pemilihan media, c) pemilihan format-format dan d) pembuatan rancangan awal. Tahap Pengembangan. Dalam tahap ini pengembang memodifikasi prototipe bahan pembelajaran. Walaupun semua bahan sudah dihasilkan pada tahap perancangan namun hasil-hasil itu harus dipandang sebagai versi awal dari bahan pembelajaran yang harus dimodifikasi sebelum menjadi versi final yang efektif. Pada tahap pengembangan, umpan balik diterima melalui evaluasi formatif. Tahap Diseminasi. Bahan-bahan pembelajaran mencapai tahapan akhir produksi apabila tes pengembangan memperoleh hasil yang konsisten dan penilaian pakar menghasilkan komentar positif. Tahap diseminasi mencakup tiga langkah yaitu : a) tes validasi, b) pengepakan dan c) difusi dan adopsi.

Model perancangan sistem pembelajaran dari Dick, Dick dan Carey (2007) terdiri dari sembilan langkah yaitu a) mengidentifikasi tujuan pembelajaran, b) melakukan analisis pembelajaran, c) mengidentifikasi karakteristik dan kemampuan awal, d) menulis tujuan-tujuan, e) menyusun butir-butir tes beracuan kriteria, f) mengembangkan strategi pembelajaran, g) mengembangkan dan memilih bahan pembelajaran, h) merancang dan melaksanakan evaluasi formatif, dan i) merevisi pembelajaran. Tampak bahwa dalam model di atas tidak ditampakkan adanya kegiatan validasi pakar (ahli).

Plomp (1992) mengajukan lima langkah desain pembelajaran yang ia sebut sebagai model umum pemecahan masalah kependidikan yang mencakup a) tahap penyelidikan/investigasi awal (preliminary investigation), b) tahap perancangan (design), c) tahap pengembangan (realization/ construction), d) tahap tes, evaluasi dan revisi (test, evaluation, and revision), dan e) tahap implementasi (implementation).

Tahap Penyelidikan Awal. Kegiatan ini disebut analisis kebutuhan atau analisis masalah. Unsur utama dalam penyelidikan ini adalah memperoleh dan menganalisa informasi, perumusan masalah dan merencanakan kegiatan lanjutan. Salah satu unsur penting dalam proses ini adalah "menentukan masalah". Dalam hal kasus kesenjangan antara situasi yang aktual dengan situasi ideal sebagai masalah, maka diperlukan penyelidikan dan pemaparan kesenjangan itu secara cermat. Dalam analisis seperti itu perlu dibedakan secara cermat antara penyebab yang ada di balik masalah dengan gejala-gejala dan sebab-sebab lain seperti perkembangan sosial dan teknologi. Dalam tahap ini perlu juga dilakukan analisis konteks, yang menggali faktor-faktor kritis dalam situasi masalah, tentang kemungkinan peran-perang orang tertentu dan tentang kondisi-kondisi yang ada.

Prasyarat utama bagi setiap kegiatan adalah pengenalan masalah, Hanyajika seseorang sadar bahwa situasi yang ada tidak memuaskan dalam satu atau beberapa hal langkah awal bisa dilakukan.

Sesudah menganalisia masalah, maka proses pemecahan masalah dapat mulai dijalankan. Langkah pertama adalah melakukan orientasi masalah. Tujuan dari langkah ini adalah untuk memperoleh tilikan umum tentang keluasan dan sifat masalah serta perlunya solusi/ pemecahan masalah. Jika diperlukan berbagai teknik yang tersedia untuk analisis atau asesmen kebutuhan pendidikan atau pelatihan dapat digunakan dalam tahapan ini. Perlu pula dikembangkan daftar tentang siapa/pihak-pihak mana yang mampu dan memiliki kewenangan untuk memecahkan masalah, batasan-batasan apa yang membatasi solusi, mana yang sudah diketahui secara luas saat ini terkait dengan kemungkinan-kemungkinan pemecahan masalah. Semua itu merupakan upaya mengumpulkan dan menganalisa berbagai aspek dari informasi yang relevan dengan masalah di tengah keterbatasan waktu. Orientasi masalah mencakup upaya untuk mempelajari 
dokumen-dokumen yang relevan, melakukan wawancara eksploratrif dengan para pihak yang memiliki kepedulian ataupun pakar, sehingga menghasilkan definisi masalah sementara.

Jika hal itu sudah dilakukan, maka analisis masalah yang lebih diperluas dapat dilakukan yang akan berujung pada rumusan masalah definitif. Untuk mencapai hal itu, diperlukan pencarian informasi yang lebih terarah dan mendalam, berdasarkan rumusan masalah sementara/ tentatif, dengan tujuan untuk memperoleh tilikan ke dalam masalah dan konteksnya, yang harus diupayakan sekomplit dan seterpecaya mungkin. Rumusan masalah yang pasti/definitifmencakup deskripsi tepat dari situasi sekarang dan situasi yang diinginkan. Dalam perumusannya perlu digambarkan secara pasti dalam kondisi-kondisi seperti apa masalah tersebut dipertimbangkan dapat dipecahkan. Perlu pula dikemukakan sarana-sarana atau fasilitasfasilitas yang harus digunakan untuk proses memecahkan masalah dan dalam keterbnatasan-keterbatan kondisi seperti apa solusi itu harus diwujudkan.

Dalam masalah pembelajaran misalnya, hal itu mengimplikasikan terumuskannya tujuan-tujuan pembelajaran melalui sarana-sarana teknik asesmen kebutuhan, dengan deskripsi situasi akhir sebagai hasil, deskripsi dari kelompok sasaran; atau dengan perkataan lain situasi pada permulaan, dan deskripsi lingkungan pendidikan/pelatihan

a) Tahap Perancangan

Pada tahap ini solusi dikembangkan dimulai dari perumusan masalah. Karakteristik dari tahap ini adalah pengembangan solusi-solusi altenatif, membanding kan dan mengevaluasi solusi-solusi alternatif tersebut, serta memilih desain atau cetak biru solusi yang paling menjanjikan. Dalam melakukan hal itu para perancang dapat menggunakan baik pengetahuan ilmiah maupun informasi praktis dari pihak-pihak yang berpengalaman. Oleh karena itu proses perancangan semestinya diwarnai oleh interaksi antara orientasi praktik dan orientasi teoritik. Kreativitas yang tinggi akan memampukan perancang untuk memadu unsurunsur pengetahuan dari berbagai bidang ilmu dan lapangan kerja yang kadang saling bertentangan.

Kegiatan-kegiatan pada tahap ini memiliki tujuan untuk merancang pemecahan masalah sebagaimana telah dirumuskan pada tahap penyelidikan awal. Hasil dari tahap perancangan adalah dokumen rancangan, sebuah cetak biru pemecahan masalah. Jika kata kunci pada tahap penyelidikan adalah analisa, maka kata kunci pada tahap perancangan adalah sintesa. Kemampuan utama yang diperlukan adalah kecakapan kreatif dari si pemecah masalah. Walaupun demikian bukan berarti bahwa dalam tahap ini tidak diperlukan kemampuan analisis. Oleh karena semua kegiatan merupakan proses sistematis maka keseluruhan masalah perlu dipilah-pilah ke dalam bagian-bagian masalah di mana bagian pemecahan masalah dijalankan secara berkelanjutan sebagai bagian dari struktur pemecahan masalah yang menyeluruh. Prinsip umumnya adalah bagi masalah ke dalam sejumlah bagian masalah yang dapat dikendalikan.

Bergantung pada sifat dari masalah, perancang dapat menerapkan pandangan-pandangan dari ilmu lain seperti ilmu organisasi, sosiologi, ilmu pendidikan, informasi, ergonomic, etika, bahasa disain grafis dan lain lain. Jika struktur pemecahan masalah dan semua tujuan-tujuan desain serta tujuan antara telah dibangun, maka kemudian perlu dibangun solusi-solusi alternatif. Sampai tahap ini pemilihan solusi tertentu belum dilakukan, karena masih dalam tahap mengembangkan pandangan menyeluruh tentang pilihan-pilihan jalan/solusi untuk mencapai situasi akhir yang dikehendaki.

Langkah berikutnya adalah membandingkan dan memberi bobot pada pilihan-pilihan yang ada. Semua pilihan pemecahan masalah dites dengan pertanyaan apakah pilihan itu memenuhi kebutuhan khusus dan apakah dapat diwujudkan dalam kondisi-kondisi yang serba terbatas. Lebih lanjut solusi-solusi itu dapat diperbandingkan dari segi biaya, keterlaksanaan, penerimaan dan kompleksitasnya. Solusi yang dipilih adalah solusi yang efektif, dapat diterima dan dapat dicapai dengan risiko dan usaha yang minimal. 
Namun pemilihan solusi bukanlah semata proses pembobotan. Kadang solusi terbaik yang mungkin justru tidak memenuhi kriteria yang ada. Kadang juga ditemukan situasi dimana masalah yang ada tidak dapat dipecahkan paling tidak dengan sarana dan pengetahuan yang ada. Pada kasus lain solusi hanya bisa berjalan dengan mengintroduksikan perubahan-perubahan tertentu. Kadang diperlukan pula adanya feasibility study.

Hasil dari kegiatan di atas adalah rencana atau cetak biru pemecahan masalah, di mana semua unsur dibuat spesifik dan sesuai dengan kebutuhan pelaksanaan pemecahan masalah itu sendiri. Solusi itu juga mempunyai fungsi pertanggungjawaban, para klien dan pihak-pihak terkait dapat secara kritis menilai kualitas dari solusi yang dipilih bahkan sebelum rencana itu dijalankan.

Pada akhir tahap perencanaan-perencanaan kegiatan dapat dilakukan kembali. Pada uraian tentang penyelidikan awal disebutkan bahwa tahap itu akan diakhir dengan penyusunan draft rencana manajemen untuk memenuhi keberlangsungan proyek. Namun demikian, hal itu hanya mungkin apabila sifat dan cakupan solusi yang akan dikembangkan sudah cukup diketahui pada tahap itu. Sering hal itu tidak terjadi dan oleh karena itu perencanaan hanya dapat menjangkau akhir dari tahap itu. Oleh karena itu pada akhir tahap desain ini rencana manajemen perlu sekali lagi dibuat untuk menjaga keberlangsungan proyek, berdasar desain yang tersedia.

b) Tahap Perwujudan atau Konstruksi

Rancangan yang sudah ditulis menjadi titik berangkat bagi perwujudan solusi yang telah disusun. Pelaksanaan rancangan solusi tersebut dapat mencakup pembuatan atau produksi kegiatan-kegiatan lain seperti pengembangan kurikulum atau produksi bahan audio visual. Berdasar desain yang rinci maka dikembangkan prototipe. Per definisi prototipe bukan sesuatu yang sudah jadi dan tujuannya justru untuk memungkinkan dilakukannya tes terhadap prototipe itu sendiri.

Membuat prototipe adalah teknik terkenal dalam pengembangan program pendidikan berbasis komputer. Dengan mensimulasikan kinerja atau penampilan program komputer semua yang terkait termasuk disainer sendiri dapat memperoleh pemahaman yang lebih baik tentang hal itu dibanding jika sekedar membacanya di atas kertas.

Dalam pemecahan masalah-masalah di bidang pendidikan, tahapan desain dan tahapan konstruksi (tahapan produksi) sering saling tumpang tindih. Beda pokok antara kedua tahap itu adalah bahwa pada tahap konstruksi keputusan keputusan teknis pelaksanaan lebih banyak dibuat ketimbang keputusan fungsional.

c) Tahap Tes, Evaluasi dan Revisi

Solusi yang dikembangkan harus dites dan dievaluasi melalui praktik. Melalui pengumpulan data dapat ditentukan apakah solusi itu sudah memuaskan atau masih memerlukan perbaikan, yang mengimplikasikan perlunya kegiatan-kegiatan suplemen pada langkah-langkah sebelumnya. Semuanya itu disebut siklus umpan balik, yang perlu diulang dan diulang lagi sampai solusi yang bersangkutan sudah bisa diterima atau dipandang memuaskan.

Tahap ini dimaksudkan untuk menilai kualitas dari solusi yang telah dikembangkan, dan membuat keputusan lanjutan berdasar hasil penilaian tersebut.

Evaluasi adalah proses sistematis pengumpulan, pemrosesan dan analisis informasi dalam rangka mengukur nilai dari pelaksanaan solusi, atau dengan perkataan lain, dalam menentukan sejauh mana pelaksanaan itu memenuhi spefisikasi rancangan. Informasi itu dikumpulkan melalui penyelenggaraan tes, atau satu kegiatan penting dalam riset yang dirancang sebagai landasan bagi pengambilan kesimpulan yang 
sahih dan terpercaya. Tanpa evaluasi sulit ditentukan apakah masalah sudah dipecahkan secara memuaskan, atau apakah situasi yang diinginkan, sebagaimana dinyatakan dalam rumusan masalah tetap, telah dicapai.

Oleh karena itu evaluasi merupakan satu karakteristik dari pendekatan masalah secara sistematis. Dalam hubungan ini, perlu dibedakan antara evaluasi formatif dengan evaluasi sumatif. Evaluasi formatif dilaksanakan selama proses pengembangan, dengan tujuan untuk menentukan apakah selama proses pengembangan diperlukan penyesuaian dari solusi yang sedang dikembangkan. Sedang evaluasi sumatif dilaksanakan pada akhir proyek dengan tujuan untuk menentukan kualitas dari produk akhir.

Evaluasi terhadap prototipe dapat mengambil bentuk bemacam-macam. Jika menyangkut metode pengajaran baru maka hal itu dapat dievaluasi dalam praktik pendidikan dengan tujuan untuk perbaikan. Mencatat hasil belajar siswa, mewawancarai para guru dan siswa baik secara langsung atau dengan mengisi kuesioner dan mengamati proses-proses pembelajaran dan belajar, merupakan hal-hal yang dapat tercakup dalam evaluasi semacam ini. Lain halnya jika rancangan itu mengenai model organisasional baru. Model semacam ini tidak dapat diimplementasikan "apa adanya" hanya untuk kepentingan evaluasi. Dalam kasus ini, jenis evaluasi lain harus digunakan, misalnya dalam bentuk asesmen oleh panel para pakar.

Bagaimanapun juga setiap evaluasi harus dirancang sedemikian agar menyediakan kesempatan maksimum untuk mendeteksi titik-titik kelemahan dari prototipe yang sedang dievaluasi. Evaluasi juga harus dilaksanakan dalam situasi yang paling dapat dikendalikan.

Berdasarkan hasil dari evaluasi dapat ditarik berbagai macam kesimpulan tentang proses pengembangan yang telah dilakukan. Tentu saja diharapkan agar hasil evaluasinya positif, sehingga solusi berdasar prototipe yang ada dapat sepenuhnya dikembangkan dan diimplementasikan. Namun, hal itu sering tidak terjadi.

Jika hasil evaluasi seluruhnya atau sebagian negatif, atau jika prototipe yang dikembangkan tidak memenuhi semua kriteria yang telah dikhususkan, maka keputusan harus diambil untuk kembali ke salah satu atau lebih tahapan sebelumnya. Revisi yang ringan adalah rancangannya tetap, namun bangunan prototipenya yang harus direvisi. Jika revisi itu tampak tidak efektif maka penyesuaian rancangan mungkin dibutuhkan. Perancang bahkan harus kembali jauh ke belakang jika ditemukan bahwa masalah justru telah dirumuskan secara tidak akurat atau tidak lengkap, sehingga harus kembali ke tahap penyelidikan awal/ pendahuluan. Kadang, siklus umpan balik dan revisi ini harus dilakukan sebelum orang sampai pada solusi yang memuaskan. Sudah barang tentu dari sisi pengawasan proyek harus dikatakan bahwa proses ulangalik itu harus dibatasi seminimum mungkin. Di lain pihak karena solusi-solusi itu mungkin mengandung unsur-unsur yang tidak diketahui atau tidak pasti, sehingga mendorong terjadinya proses ulang-alik yang berkepanjangan, maka pendekatan eksperimen perlu dilakukan.

d) Tahap Implementasi

Pada tahap ini solusi dilaksanakan. Program pelatihan baru, misalnya, akan dilaksanakan oleh para pengembang atau para pelatih, yang dapat dimasukkan ke dalam program pelatihan yang sudah ada. Pada tahap-tahap pengembangan terdahulu kita sudah memiliki kontak intensif dengan 'orang-orang yang terlibat atau yang memiliki perhatian'. Pihak-pihak yang memiliki perhatian bukanlah semata para klien yang berkepentingan dengan sisi keuangan, melainkan juga orang-orang lain, seperti para guru, siswa atau peserta pelatihan.

Hanya jika telah disimpulkan, berdasar evaluasi, bahwa solusi memuaskan bagi masalah yang ada telah dikembangkan, maka solusi itu dapat diimplementasikan, atau dijalankan dalam situasi di mana masalah itu benar-benar ada. Oleh karena sudah ada tahap evaluasi maka menjadi jelas bahwa implementasi hanya punya satu kemungkinan untuk sukses, jika yakin bahwa hal itu diterima oleh para pihak yang peduli terhadap situasi masalah. Dalam beberapa model desain posisi dari evaluasi dan implementasi sering dibalik. 
Dalam rangka implementasi berbagai macam kegiatan mungkin diperlukan, seperi kampanye informasi, mengaktifkan pihak-pihak yang terkait, melaksanakan konferensi, pelatihan dalam jabatan, atau pelatihan kembali bagi para guru, diawali dulu atau tidak diawali dulu dengan "training of trainers" (TOT). Untuk melaksanakan berbagai kegiatan tersebut rencana implementasi harus dibuat, idealnya sudah di buat pada permulaan proyek pengembangan. Dengan merancang rencana itu maka pemilihan strategi implementasi menjadi penting. Strategi itu akan menentukan serangkaian langkah mana yang diperlukan untuk mencapai pengenalan inovasi yang berhasil, dan kebutuhan penyesuaian diri terhadap sifat dan kompleksitas dari proses perubahan yang dibutuhkan. Hasil dari implemetasi adalah berfungsinya dan diterimanya solusi yang ditawarkan.

Dalam praktik, proses perancangan jarang berlangsung dalam tahapan yang terurut benar seperti tahapan tersebut di atas. Pada setiap tahapan sangat mungkin diperlukan untuk kembali ke tahapan sebelumnya. Oleh karena itu masing-masing tahapan dalam model perancangan ini memang dapat dibedakan secara jelas, namun dalam pelaksanaannya sering tidak dapat dibedakan secara tegas.

\section{METODE PENGEMBANGAN}

Sesuai dengan langkah-langkah pengembangan disain pembelajaran dari Plomp (1992) maka pengembangan Model PAKAR juga dilakukan melalui tahap-tahap: a) penyelidikan/investigasi awal (preliminary investigation), b) perancangan (design), c) pengembangan (realization/construction), d) tes, evaluasi dan revisi (test, evaluation, and revision), dan e) implementasi (implementation).

Dalam tahap penyelidikan awal, dilakukan studi literatur tentang teori dan praktik pembelajaran guna menemukan masalah-masalah dalam pembelajaran PKn dan faktor-faktor yang mempengaruhinya. Di samping itu dilakukan pula focuss group discussion (FGD) dengan guru-guru PKn SMP, SMAdan SMK di Salatiga, untuk mengkonfirmasi temuan-temuan dalam studi literatur tentang masalah riil yang dihadapi para guru dalam proses pembelajaran.

Tahap Perancangan. Pada tahap ini solusi dikembangkan, mulai dari perumusan masalah dan pengembangan solusi alternatif pemecahan masalah. Tujuan yang akan dicapai melalui kegiatan ini adalah merancang pemecahan masalah sebagaimana telah dirumuskan pada tahap penyelidikan awal. Kegiatan yang dilakukan adalah studi dan diskusi intensif antar para anggota Tim Pengembang guna menemukan kerangka model yang tepat bagi pembelajaran PKn.

Tahap Implementasi. Setelah model diujicobakan di sekolah dan direvisi, dilanjutkan implementasi model PAKAR. Implementasi model bertujuan untuk mensosialisasikan model yang dilakukan melalui pelatihan bagi guru-guru mata pelajaran PKn SMP dan SMA di Salatiga. Selanjutnya dilakukan eksperimen model untuk mengetahui efektifitasnya. Model eksperimen yang digunakan adalah quasi eksperimen yaitu menggunakan kelompok eksperimen dan kelompok kontrol untuk membandingkan prestasi belajar PKn pada siswa yang mengikuti pembelajaran dengan model PAKAR dengan kelompok siswa yang mengikuti pembelajaran dengan metode konvensional. Langkah-langkah pengembangan model PAKAR secara garis besar dapat dilihat pada gambar 1, berikut. 


\section{LANGKAH-LANGKAH PENGEMBANGAN MODEL PAKAR}

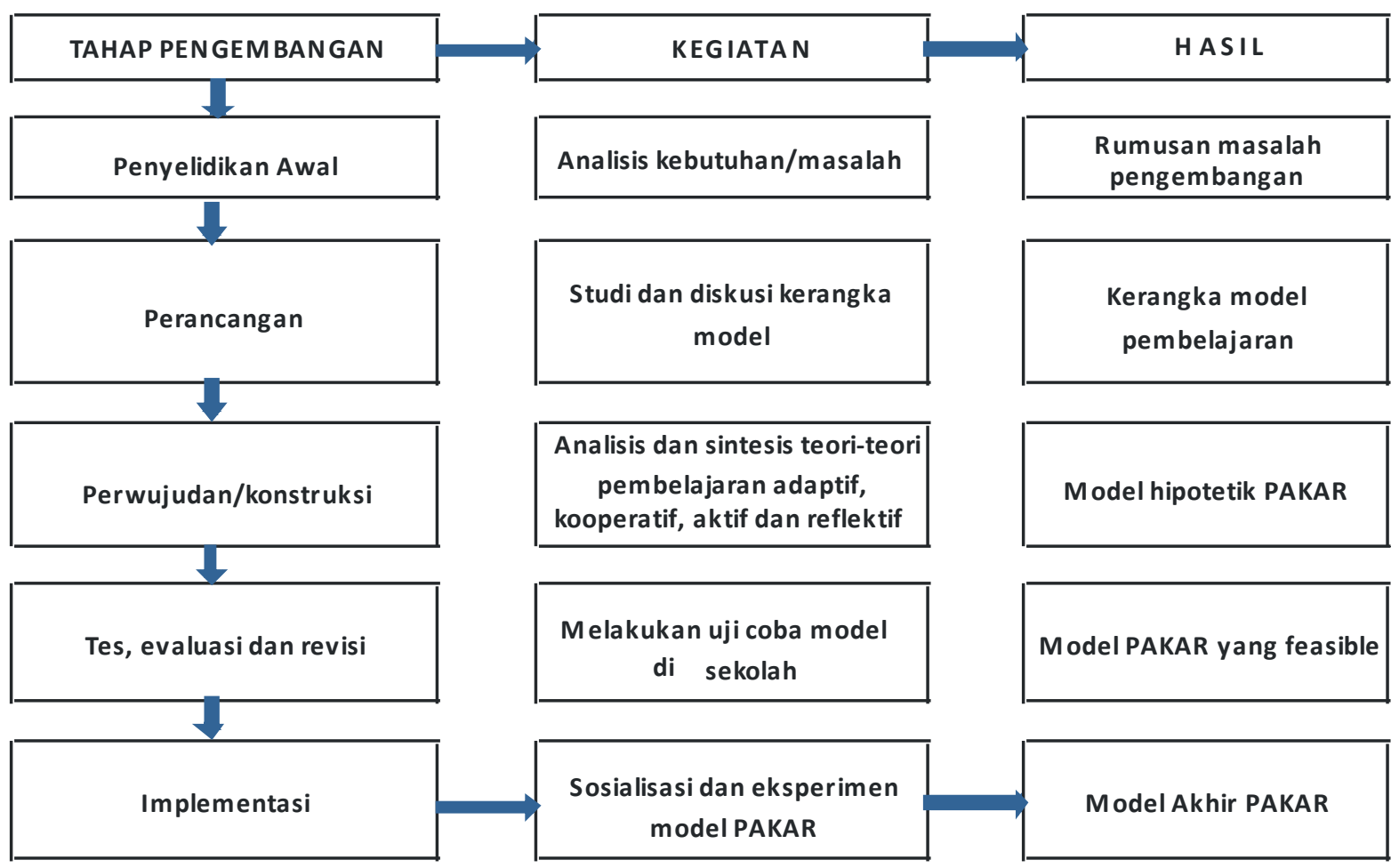

Gambar 1. Pengembangan model PAKAR

\section{HASIL PENGEMBANGAN}

1. Tahap penyelidikan awal. Melalui kegiatan menentukan masalah dalam pembelajaran Pendidikan Kewarganegaraan melalui studi literatur dan FGD dengan guru PKn, diperoleh gambaran masalah bahwa muatan materi PKn begitu padat, sangat terbatasnya waktu yang tersedia untuk melaksanakan pembelajaran inovatif, tumpang tindihnya materi Pendidikan Kewarganegaraan antar jenjang pendidikan, rendahnya kreativitas Guru dalam mengembangkan pembelajaran inovatif, kurang memadainya sarana dan prasarana sekolah yang diperlukan untuk mengembangkan dan menerapkan pembelajaran inovatif, kurangnya dukungan dari pihak sekolah yang sebenarnya amat diperlukan Guru dalam mengembangkan pembelajaran PKn yang inovatif, dan motivasi siswa untuk belajar PKN rendah. Salah satu penyebab yang diduga oleh para Guru adalah karena PKn bukan mata pelajaran yang diuji-nasionalkan. Walaupun demikian kebanyakan Guru juga menyadari adanya peluang yang tersedia bagi dilakukannya pembelajaran inovatif dalam PKn, yaitu dewasa ini tersedia banyak model/strategi pembelajaran mutakhir bagi pembelajaran PKn. Temuan tersebut memumpun pada satu kesimpulan bahwa memang diperlukan model pembelajaran yang mampu menjembatani kesenjangan antara tujuan ideal matapelajaran PKn dengan kondisi lapang di mana matapelajaran itu harus diajarkan.

2. Tahap perancangan. melalui studi dan diskusi intensif antar para anggota Tim Pengembang ditemukan kerangka model yang tepat bagi pembelajaran PKn. Dari studi diskusi itu diperoleh kesimpulan bahwa telah terjadi sejumlah perubahan baik dalam bidang pembelajaran, manajemen sekolah dan tujuan mata pelajaran PKn yang harus diakomodasi dalam pengembangan model pembelajaran PKn. 
3. Tahap konstruksi atau pengembangan. Tim Pengembang mulai membangun prototipe model PAKAR. Penyusunan diarahkan pada upaya untuk membangun model pembelajaran yang baik yaitu yang memenuhi kebutuhan akan model pembelajaran yang cocok untuk pembelajaran Pendidikan Kewarganegaraan, dan sekaligus memenuhi persyaratan model pembelajaran yang baik, yaitu: a) kokoh bangunan teoritisnya, b) valid topangan hasil penelitian tentang efektifitas modelnya, dan c) teruji prosedur pelaksanaan bakunya.

Sejauh ini pengembangan yang dilakukan baru sampai pada tersusunnya prototip model pembelajaran PAKAR atau pada tahap konstruksi model, yang terdiri atas bangunan teori fondasi PAKAR dan sintaks model PAKAR.

\section{Fondasi Teoritis PAKAR}

Model PAKAR dibangun atas dasar konstruktivisme yang menurut Savery \& Duffy (1996) memuat prinsip-prinsip pembelajaran sebagai berikut:

a. Meletakkan/mengkaitkan kegiatan belajar ke dalam tugas-tugas atau masalah yang lebih besar. Belajar harus mempunyai tujuan diluar "yang ditugaskan". Tujuan setiap belajar harus jelas bagi si belajar. Kegiatan belajar perorangan dapat bermacam macam, tetapi isu terpentingnya adalah bahwa si belajar benar- benar memahami dan menerima kegiatan belajar khusus dalam relasinya dengan tugas kompleks yang lebih besar.

b. Mendukung siswa dalam mengembangkan kepemilikan atas keseluruhan tugas-tugas atau masalah. Program pembelajaran umumnya mempunyai tujuan tujuan belajar yang harus dicapai siswa dan mungkin bahkan melibatkan si belajar dalam projek tertentu. Selalu diasumsikan bahwa si belajar memahami dan meyakini relevansi serta nilai dari masalah yang harus dipecahkannya. Sayangnya, terlalu sering bahwa si belajar tidak memahami tujuan dari program pembelajaran yang ia jalani, dan sekedar meusatkan diri pada usaha menyelesaikan tugas atau sekedar mengisi waktu dalam belajar. Oleh karena itu adalah penting agar tujuan-tujuan yang dibawa oleh si belajar ke dalam lingkungan belajar sejalan dengan tujuan-tujuan pembelajaran yang kita tetapkan.

Ada dua cara untuk melakukan hal itu. Pertama, kita dapat mengumpulkan masalah dari siswa dan menggunakannya sebagai stimulus bagi kegiatan belajar. Scarmandala dan Bereiter (1991) telah menunjukkan bahwa bahkan siswa sekolah dasar pun dapat mengajukan pertanyaan atau teka-teki yang dapat dijadikan dasar kegiatan belajar. Alternatifnya, kedua, kita dapat membangun masalah sedemikian sehingga siswa siap mengadopsi masalah itu sebagai masalahnya. Dalam kedua kasus itu penting untuk melibatkan si belajar dalam dialog bermakna untuk membantu mereka membawa masalah atau tugas ke pada si belajar.

c. Mendesain tugas yang otentik. Lingkungan belajar otentik adalah lingkungan yang tuntutan-tuntutan kognitifnya, misalnya tingkat berpikir yang diperlukan, sejalan dengan tuntutan-tuntutan kognitif dalam lingkungan yang kita persiapkan bagi si belajar kelak (Honebein, et al,. 1993). Dalam mata pelajaran sejarah misalnya, kita tidak ingin agar si belajar belajar tentang sejarah sekedar menghafal peristiwa dan tanggalnya, tetapi sebenarnya hendak melibatkan siswa dalam mengkonstruksi atau menggunakan sejarah dalam cara yang biasanya digunakan oleh sejarawan atau warganegara yang baik. Demikian juga, kita tidak menginginkan agar si belajar mempelajari sains - mengingat teks sains atau melaksanakan prosedur saintifik yang didiktekan- melainkan lebih melibatkan mereka dalam wacana sains dan pemecahan masalah sains (lihat Bereiter, 1994, Duffy, Honebein et al,. 1993).

d. Mendesain tugas-tugas dan lingkungan belajar yang merefleksikan kompleksitas lingkungan yang kelak akan dihadapi si belajar. Ketimbang menyederhanakan lingkungan bagi si belajar, kita 
berupaya mendukung si belajar bekerja dalam lingkungan yang kompleks. Hal ini sejalan baik dengan konsep 'pemagangan kognitif' (Collin, Brown, \& Newman, 1989) maupun teori kelenturan kognitif (Spiro dkk, 1992) dan sekaligus menegaskan tentang pentingnya konteks terhadap pemahaman kita tentang konsep atau prinsip tertentu.

e. Memberikan kesempatan kepada si belajar untuk menentukan sendiri bagaimana proses yang akan ia gunakan dalam membangun solusi. Pembelajar harus menentukan sendiri proses belajar atau pemecahan masalah terhadap masalah yang sudah ia pilih sendiri. Seringkali Guru memberi kesempatan pada si belajar untuk memilih sendiri masalah yang akan dipecahkannya, namun mendiktekan proses untuk mengerjakan masalah itu, sehingga si belajar tidak terlibat dalam berpikir otentik atau tidak terlibat dalam pemecahan masalah secara otentik. Dalam kasus semacam itu masalah bukannya berperan sebagai stimulus bagi belajar pemecahan masalah atau belajar mandiri melainkan sekedar sebagai sebuah contoh. Peran Guru dengan demikian harus menantang berpikir si belajar - bukan mendiktekan atau berusaha memprosedurkan cara berpikir si belajar.

f. Mendesain lingkungan belajar yang mendukung dan menantang berpikir si belajar. Senyampang kita menekankan pentingnya memberi si belajar masalah dan proses solusi sendiri, tetapi disadari bahwa setiap kegiatan atau solusi itu memadai. Tujuannya adalah mendukung si belajar agar menjadi pemikir/ pekerja efektif dalam domain tertentu. Guru harus berperan sebagai konsultan atau pelatih. Kegiatan mengajar yang paling menentukan adalah saat Guru mengajukan pertanyaan kepada si belajar. Di samping menghargai Guru juga harus menantang berpikir si belajar. Guru tidak boleh mengambil alih berpikirnya si belajar dengan memberitahu mereka apa yang harus dilakukan atau bagaimana cara berpikir, melainkan lebih mendorong si belajar untuk melakukan inkuiri (Fosnot, 1989). Konsep 'bantuan belajar' dan zona perkembangan terdekat, sebagaimana dideskripsikan oleh Vygostsky (1978) merupakan represetasi yang lebih akurat tentang pertukaran/interaksi belajar antara Guru dan si belajar di atas. Si belajar menggunakan sumber sumber belajar (semua jenis media) dan materi pelajaran (semua jenis media) sebagai sumber informasi

g. Mendorong pengujian ide-ide terhadap pandangan-pandangan dan konteks-konteks alternatif. Pengetahuan adalah sesuatu yang dinegosiasikan secara sosial. Kualitas atau kedalaman pemahaman seseorang hanya dapat ditentukan dalam lingkungan sosial di mana kita dapat melihat apakah pemahaman kita dapat mengakomodasi isu-isu dan pandangan-pandangan dari orang lain dan untuk melihat jika terdapat sudut sudut pandang yang dapat kita padukan ke dalam pemahaman kita. Komunitas belajar di mana ide-ide didiskusikan dan pemahaman diperkaya adalah sangan penting dalam mendesain lingkungan belajar yang efektif. Penggunaan kelompok-kelompok belajar kolaboratif sebagai bagian dari keseluruhan lingkungan belajar yang telah didiskripsikan memberikan satu strategi untuk mencapai komunitas belajar itu (CTGV, 1994; Cunningham, Duiffy, \& Knuth, 1991; Scardamalia dkk, .1992).

h. Menyediakan kesempatan dan memfasilitasi proses refleksi baik terhadap konten yang dipelajari maupun proses belajar. Tujuan penting dari pembelajaran adalah untuk mengembangkan ketrampilan mengatur diri sendiri agar menjadi pribadi yang mandiri. Guru harus memodelkan berpikir reflektifmelalui proses belajar dan dukungan pada si belajar dalam merefleksikan dalam strategi-strategi belajar maupun apa yang harus dipelajari (Clift, Houston, \& Pugach, 1990; Schom, 1987).

Namun, penerapan prinsip-prinsip pembelajaran konstruktivisme juga bersifat selektif karena beberapa prinsip pembelajaran behavioristik masih relevan diterapkan. Jonassen, 1992 (dalam Westwood, 2008) menyampaikan tiga tingkatan model pemerolehan pengetahuan, yang dinamakan: (1) Tingkat 1 awal pemerolehan pengetahuan; (2) Tingkat 2 -pengetahuan tingkat lanjut; (3) Tingkat 3 - ahli. Dia 
mendukung pandangan bahwa awal pemerolehan pengetahuan akan lebih baik diajarkan melalui pengajaran langsung dan bahwa pengetahuan tingkat lanjut sampai ke tingkat ahli akan lebih menguntungkan jika diajarkan melalui pendekatan konstruktivis. Sebagai contoh, dalam area pengajaran baca tulis, membangun ketrampilan dasar yang melibatkan membaca awal, seperti pengenalan kata dan mengolah pesan, mungkin paling baik diajarkan melalui pengajaran langsung, sedangkan membaca yang lebih kritis tingkatannya dan memerlukan pemahaman mendalam mungkin mewakili pengetahuan lebih lanjut dan ahli dibangun berdasarkan fondasi kokoh yang diciptakan oleh pengajaran langsung sebelumnya. Sama halnya, pengetahuan lebih lanjut dan ahli membutuhkan pemecahan masalah matematika yang lebih tinggi paling baik dikembangkan dari fondasi kokoh ketrampilan angka dasar dan pengertian mengenai angka yang dikembangkan melalui pengajaran langsung sebelumnya.

Model PAKAR yang dikembangkan telah memenuhi persyaratan prinsip-prinsip pembelajaran konstruktivis yang dipadu dengan unsure behavioristik di atas sebagai berikut.

Dimensi adaptif dalam pembelajaran yang dianjurkan dalam PAKAR dimaksudkan untuk memenuhi prinsip-prinsip 1 -4, yaitu: (1) meletakkan/mengkaitkan kegiatan belajar ke dalam tugas-tugas atau masalah yang lebih besar; (2) mendukung siswa dalam mengembangkan kepemilikan atas keseluruhan tugas-tugas atau masalah; (3) mendesain tugas yang otentik; (4) mendesain tugas-tugas dan lingkungan belajar yang merefleksikan kompleksitas lingkungan yang kelak akan dihadapi si belajar.

Dimensi aktif dan kooperatif dalam PAKAR dimaksudkan untuk memenuhi prinsip pembelajaran konstruktivis yang ke 5 - 7 yaitu memberikan kesempatan kepada si belajar untuk menentukan sendiri bagaimana proses yang akan ia gunakan dalam membangun solusi, mendesain lingkungan belajar yang mendukung dan menantang berpikir si belajar dan mendorong pengujian ide-ide terhadap pandanganpandangan dan konteks-konteks alternatif.

Dimensi reflektif dalam PAKAR dimaksudkan untuk memenuhi prinsip pembelajaran konstruktivis ke 8 yaitu menyediakan kesempatan dan memfasilitasi proses refleksi baik terhadap konten yang dipelajari maupun proses belajar.

Di samping itu, model PAKAR juga dimaksudkan untuk memenuhi prinsip tahap-tahap pemerolehan pengetahuan menurut Jonnasen yang berpandangan bahwa awal pemerolehan pengetahuan akan lebih baik diajarkan melalui pengajaran langsung dan pengetahuan tingkat lanjut sampai ke tingkat ahli akan lebih menguntungkan jika diajarkan melalui pendekatan konstruktivis.

\section{Sintaks PAKAR}

Model pembelajaran adaptif, kreatif, aktif dan reflektif(PAKAR) adalah model pembelajaran yang mengintegrasikan pemahaman terhadap modalitas belajar siswa dengan teknik-teknik pembelajaran yang mengaktifkan siswa, mengembangkan kecakapan sosial siswa dan kemampuan merefleksikan pengalaman belajar mereka. Untuk mencapai tujuan tersebut digunakan berbagai strategi pembelajaran secara sinergi yaitu pembelajaran adaptif, kooperatif, aktif dan reflektif.

Pembelajaran adaptif merupakan proses pembelajaran dengan menyesuaikan kondisi, kebutuhan dan lingkungan siswa sehingga terjadi penguasaan pengetahuan, sikap dan keterampilan. Proses adaptif dilakukan dengan mengukur modalitas belajar siswa dan mempertimbangkannya di dalam proses mendesain pembelajaran. Modalitas belajar adalah cara seseorang menyerap informasi melalui indera yang dimiliki. Masing-masing orang mempunyai kecenderungan berbeda-beda dalam menyerap informasi yakni penyerapan melalui visual, auditory, kinestetik dan reading. Model pembelajar visual menyerap informasi dan belajar dari apa yang dilihat oleh mata. Di sini individu memiliki kecenderungan gaya belajar visual lebih senang dengan melihat apa yang sedang dipelajari. Gambar atau visualisasi akan membantu mereka 
yang memiliki gaya belajar visual untuk lebihmemahami ide informasi yang disajikan dalam bentuk penjelasan. Sedangkan model pembelajar auditori adalah model di mana seseorang lebih cepat menyerap informasi melalui apa yang ia dengarkan. Penjelasan tertulis akan lebih mudah ditangkap oleh para pembelajar auditori ini. Karakteristik model belajar seperti ini benar-benar menempatkan pendengaran sebagi alat utama menyerap informasi atau pengetahuan, artinya anak harus mendengar, baru kemudian bisa mengingat dan memahami informasi yang diterima. Berbeda dengan gaya belajar auditori, model pembelajar kinestetik adalah pembelajar yang menyerap informasi melalui berbagai gerakan fisik. Individu yang memiliki kecenderungan gaya belajar kinestetik akan lebih baik apabila terlibat secara fisik dalam kegiatan langsung. Yang terakhir, orang yang memiliki gaya belajar reading yaitu belajar dengan menitikberatkan pada tulisan atau catatan. Karakteristik ini benar-benar menempatkan bacaan atau tulisan sebagai alat utama untuk menyerap informasi atau pengetahuan. Berdasarkan macam-macam gaya belajar tersebut, seorang guru perlu memahami gaya belajar siswa-siswanya sehingga dapat mendesain pembelajaran yang dapat mengakomodasi berbagai gaya belajar siswa.

Pelaksanaan pembelajaran dengan model PAKAR menggunakan 3 strategi pembelajaran yaitu pembelajaran kooperatif, pembelajaran aktif dan pembelajaran reflektif. Pembelajaran kooperatif adalah pembelajaran yang memanfaatkan kelompok-kelompok kecil sehingga siswa bekerja sama untuk memaksimalkan proses belajar mereka sendiri dan teman-temannya. Dalam model pembelajaran kooperatif terdapat sejumlah teknik untuk membelajarkan siswa melalui proses kelompok. Pemanfaatan berbagai teknik tersebut sangat bergantung pada tujuan pembelajaran, karakteristik materi, ketersediaan sarana dan prasarana, waktu. Pilihan terhadap penggunaan teknik kooperatif tertentu merupakan otoritas Guru setelah mempertimbangkan berbagai aspek tersebut agar siswa dapat mengembangkan kecakapan sosialnya. Pembelajaran Kooperatif memiliki 5 karakteristik, yaitu: (a) kesalingtergantungan positif antarindividu [positive interdependence], (b) interaksi tatap muka secara langsung [face-to-face interaction], (c) tanggungjawab perseorangan [individual accountability], (d) keterampilan antar-pribadi dan kelompok kecil [social skills], (e) evaluasi proses kelompok [group processing]. Pembelajaran Kooperatif terdiri atas enam aktivitas utama yang harus dilakukan secara berurutan oleh guru. Keenam aktivitas itu meliputi: (a) menentukan tujuan pembelajaran secara spesifik; (b) membuat keputusan-keputusan prapembelajaran; (c) menjelaskan susunan tugas dan tujuan kepada siswa; (d) melaksanakan pembelajaran; (e) memonitor efektivitas kelompok; dan(f) mengevaluasi pencapaian siswa serta proses kelompok.

Pembelajaran yang bertumpu pada upaya mengaktifkan siswa dalam belajar adalah pembelajaran aktif. Pembelajaran aktif terdiri dari dua komponen utama yaitu: unsur pengalaman (experience), meliputi kegiatan melakukan (doing) dan pengamatan (obeserving) dan dialogue, meliputi dialog dengan diri sendiri (self) dan dialog dengan orang lain (others). Dalam model pembelajaran aktif terdapat sejumlah teknik yang dapat digunakan baik untuk membuat siswa saling mengenal satu sama lain (team building), memperoleh pengetahuan secara aktif, mengembangkan sikap secara aktif, menguasai ketrampilan secara aktif maupun untuk menutup pembelajaran secara aktif. Pemanfaatan berbagai teknik tersebut sangat bergantung pada tujuan pembelajaran, karakteristik materi, sarana dan prasarana serta waktu yang tersedia. Pilihan terhadap penggunaan teknik pembelajaran aktif tertentu merupakan otoritas guru setelah mempertimbangkan berbagai aspek tersebut.

Pada bagian akhir dari suatu proses pembelajaran diciptakan situasi yang memungkinkan siswa untuk merefleksikan pengalaman belajar yang meliputi keseluruhan aktifitas intelektual, emosional seseorang dalam mengeksplorasi pengalamannya menuju pada pemahaman dan pengalaman yang baru. Proses kegiatan ini dinamakan pembelajaran reflektif, dimana dalam kegiatan ini dapat dilaksanaan setelah konsep-konsep baru dipahami oleh para siswa yang diikuti dengan kegiatan menghadirkan kembali pengalaman, mengelola 
perasaan, dan mengevaluasi kembali pengalaman. Refleksi merupakan keseluruhan aktivitas pikiran [intektual] dan perasaan [emosional] seseorang dalam mengeksplorasi pengalamannya menuju pada pemahaman dan pemaknaan yang baru. Hal itu bisa dilakukan secara perorangan atau pun dalam kerja sama dengan orang lain.

Dari paparan tersebut dapat dirangkum bahwa penerapan model PAKAR dilaksanakan dengan langkah-langkah: (1) menganalisis modalitas siswa sebagai bahan pertimbangan dalam mendesain dan melaksanakan pembelajaran; (2) mendesain dan melaksanakan pembelajaran dengan pendekatan pembelajaran aktif dan kooperatif; (3) mendesain dan melaksanakan pembelajaran reflektif; (4) melakukan evaluasi proses selama pelaksanaan pembelajaran dan evaluasi hasil untuk mengukur ketercapaian tujuan pembelajaran yang telah ditetapkan. Secara rinci, langkah-langkah penerapan model PAKAR dalam pembelajaran adalah sebagai berikut:

1. Pada tahap pra-pembelajaran:

a. Mengukur modalitas siswa dengan instrumen pengukuran gaya belajar kemudian mengolah dan menganalisis data sehingga diketahui gaya belajar masing-masing siswa di kelas tersebut.

b. Menyusun RPP dengan mempertimbangkan modalitas siswa terutama pada aspek kegiatan pembelajaran (pemilihan strategi, materi, media dan evaluasi). Pemilihan strategi pembelajaran hendaknya memperhatikan komponen-komponen PAKAR lainnya yaitu strategi kooperatif, aktif dan reflektif. Penerapan ketiga strategi tersebut tidak harus dilakukan dalam satu kali tatap muka, namun dapat beberapa kali tatap muka untuk pencapaian satu standar kompetensi dan beberapa kompetensi dasarnya.

2. Melaksanakan pembelajaran

a. Penerapan teknik-teknik pembelajaran aktif. Pilih satu atau beberapa teknik pembelajaran aktif yang sesuai dengan tujuan, hakekat materi, ketersediaaan media dan lingkungan belajar lainnya.

b. Penerapan teknik pembelajaran kooperatif. Pilih satu atau beberapa teknik pembelajaran kooperatif yang sesuai dengan tujuan, hakekat materi, ketersediaaan media dan lingkungan belajar lainnya. Langkah-langkahnya:

- Pembentukan kelompok dan pembagian tugas antar siswa yang jelas

- Membangun semangat gotong royong

- Penataan ruang kelas

- Pembagian tugas dan materi

- Memfasilitasi kerja kelompok

- Memotivasi siswa agar saling berinteraksi.

- Memfasilitasi siswa menyajikan hasil kerja kelompok.

- Memberikan umpan balik terhadap hasil kerja kelompok siswa.

- Mengevaluasi hasil belajar siswa baik secara individu maupun kelompok.

- Merencanakan kegiatan tindak lanjut pembelajaran melalui kegiatan remedial atau pengayaan.

c. Penerapan pembelajaran reflektif. Guru memandu siswa dalam melaksanakan refleksi atas proses pembelajaran dan hasil belajar yang telah dicapai. Langkah-langkah pembelajaran reflektif:

- Penyajian pengalaman. Guru memandu penyajian pengalaman langsung atau tidak langsung melalui kegiatan membaca, mendengarkan atau menyimak gambar, simulasi, permainan peran, atau tayangan audio-visual. Pada tahap ini, siswa menghayati pengalaman langsung atau melalui membaca, mendengarkan atau menyimak gambar, simulasi, permainan peran atau tayangan audio visual. 
- Refleksi. Guru mengajak siswa untuk menggali makna dan konsekuensi dari suatu pengalaman. Dapat dilakukan dengan: memahami dengan lebih baik kebenaran yang dipelajarinya; memahami sumber-sumber perasaan dan reaksi yang dialami siswa ketika merenungkan pengalaman tersebut; memperdalam pemahaman siswa tentang implikasi-implikasi bagi diri sendiri maupun orang lain; mendapatkan pengertian pribadi tentang peristiwa-peristiwa, gagasan-gagasan, kebenaran atau pemutar balikan kebenaran; memahami siapa saya (siswa) dan bagaimana seharusnya sikap saya (siswa) terhadap orang lain.

- Aksi. Guru memfasilitasi siswa agar dapat melakukan aksi melalui langkah membangun komitmen dan menyatakan pilihan hidup.

- Evaluasi. Guru melakukan evaluasi perkembangan pribadi siswa dan kepeduliannya kepada sesama, melalui observasi dengan lembar pengamatan, skala sikap dan daftar cek (checklist)

Dengan sintaks tersebut saat ini sedang dilakukan uji coba model oleh 2 (dua) orang guru PKn yaitu 1 guru SMP dan 1 guru SMA di Salatiga. Standar kompetensi yang akan dikuasai siswa dalam uji coba PAKAR di SMAadalah menampilkan peran serta dalam upaya pemajuan, penghormatan dan perlindungan Hak Asasi Manusia (HAM). Dalam uji coba tersebut melaksanakan RPP yang telah disusun oleh pengembang, yang dilaksanakan dalam 3 kali pertemuan. Pada pertemuan pertama menerapkan pembelajaran aktif dengan teknik "reportase" dan "kritik video", pada pertemuan kedua menggunakan pembelajaran kooperatif dengan teknik "jigsaw", sedang pada pertemuan ketiga menggunakan pembelajaran reflektif.

Pokok bahasan yang diujicobakan dalam uji coba PAKAR di SMP adalah Otonomi Daerah. Dalam uji coba tersebut guru melaksanakan RPP yang telah disusun oleh pengembang, yang dilaksanakan dalam 3 kali pertemuan. Pada pertemuan pertama menerapkan pembelajaran aktif, pada pertemuan kedua menggunakan pembelajaran kooperatif dengan teknik "jigsaw", sedang pada pertemuan ketiga menggunakan pembelajaran reflektif.

\section{PENUTUP}

Pengembangan model PAKAR dimaksudkan untuk memenuhi kebutuhan model pembelajaran yang cocok untuk pembelajaran PKn dan mampu mengatasi masalah dalam pembelajaran PKn. Pengembangan model pembelajaran PAKAR ini menggunakan model umum pemecahan masalah kependidikan dari Plomp (1992) yang mencakup a) tahap penyelidikan/investigasi awal (preliminary investigation), b) tahap perancangan (design), c) tahap pengembangan (realization/construction), d) tahap tes, evaluasi dan revisi (test, evaluation, and revision), dan e) tahap implementasi (implementation).

Pengembangan pembelajaran model PAKAR baru sampai pada tahap konstruksi dengan hasil akhir prototipe model pembelajaran PAKAR, dan sedang dilaksanakan kegiatan untuk tahap Tes, Evaluasi dan Revisi melalui uji coba PAKAR di sekolah. Jika prototipe model yang dikembangkan sudah mengalami proses penyempurnaan dengan memanfaatkan pendapat pakar dan hasil uji coba terbatas, maka kemudian akan dilaksanakan tahap implementasi melalui diseminasi model, dan upaya pengadopsian model tersebut oleh para Guru PKn, dan sekolah-sekolah seluas mungkin.

\section{DAFTAR PUSTAKA}

Budiardjo, M. 1980. Dasar-Dasar Ilmu Politik. Jakarta: Gramedia

Departemen Pendidikan Nasional, 2003. Pedoman Khusus Pengembangan Silabus dan Penilaian Mata Pelajaran Kewarganegaraan; Jakarta: Dirjend Pendidikan Menengah Umum. 
Departemen Pendidikan Nasional Republik Indonesia. 2006. Peraturan Menteri Pendidikan Nasional Nomor 22 Tahun 2004 tentang Standar Isi untuk Satuan Pendidikan Dasar dan Menengah. Jakarta: Depdiknas.

Dick, W., Dick, G \& Carey, L. 1990. The Systematic Design of Instruction; London: Scott, Foresman and Company.

Kompas, 16 Desember, 2000. Budi Pekerti Siap Dilaksanakan di Sekolah.

Kompas, 14 Februari. 2001. "Pustaka Anak Nusantara”; Biarkan Bersaing dengan Shinchan.

Patrick, J.J. 2001. Concepts At The Core of Education for Democratic Citizenship dalam Charles F. Bahmueller and John. J. Patrick (eds) Principles and Practices of Education for Democratic Citizenship.

Richey, R. 1986. The Theoretical and Conceptual Bases of Instructional Design; London: Kogan Page.

Savery. J.R. \& Duffy, T.M. 1996. Problem based Learning: An Instructional Model and Its Constructivist Framework; dalam Brent G. Wilson (ed) Constructivist Learning Environments. Case Studies in Instructional Design; New Jersey: Educational Technology Publications)

Thiagarajan,S., Semmel, D.S. \& Semmel, M.I. 1974. Instructional Development for Training Teachers of Exceptional Children. A Sourcebook; Minnesota: Leadership Training Institute.

Tjeerd Plomp \& Jan v d Wolde. 1992. The General model for systematical problem solving; dalam Tj. Plomp, et.all (eds). Design of Education and Training (in Dutch), Untrech (the Nederlands): Lemma. 